\title{
EVALUASI DALAM PENDIDIKAN SEBAGAI ALAT UKUR HASIL BELAJAR
}

\author{
Alif Achadah \\ Universitas Islam Raden Rahmat Malang \\ achadahalif@gmail.com
}

\section{Abstrak}

Education is one of the organizations that aims to make someone better in a variety of things so they can compete in the times. Education is said to be successful if the education produces output or graduates who are able to answer the challenges of the times. The aim of national education is to educate the nation's life and efforts to develop the whole person. The effort to improve the intelligence of national life is in various fields of life such as economics, politics, security, health, and so forth. While the success of education can be known by the evaluation process which is currently better known as the educational evaluation. Related to the evaluation process, the evaluation process in its development does not only concern student achievement but in this case the evaluation of learning also involves all kinds of things that exist in educational institutions including the extent to which the goals in the educational institution have been achieved.

Kata kunci:pendidikan, evaluasi, peserta didik, hasil belajar

\section{A. PENDAHULUAN}

Dalam evaluasi selalu mengandung proses. Proses evaluasi harus tepat terhadap tipe tujuan yang biasa dinyatakan dalam tingkah laku, dikarenakan tidak semua tingkah laku dapat dinyatakan dengan alat evaluasi yang sama, maka dari itu evaluasi menjadi salah satu hal yang sangat sulit dan menan- 
tang, yang harus disadari oleh peserta didik. Beberapa tingkah laku yang sering muncul serta menjadi pusat perhatian peserta didik yaitu tingkah laku yang dapat dikelompokkan menjadi dua, yaitu diantaranya pengetahuan intelektual seperti keterampilan yang menghasilkan tindakan. Evaluasi harus dilakukan secara sistematis agar bisa menggambarkan kemampuan para pendidik yang di evaluasi. Yang sering terjadi dalam kesalahan utama evaluasi hanya di lakukan pada saa - saat tertentu oleh pendidik, seperti pada akhir unit, pertengahan, dan akhir suatu program pembelajaran. Akibat yang terjadi adalah minimnya informasi tentang perlakuan dalam menentukan posisi pendidik, oleh karena itu untuk mendapatkan informasi yang banyak dalam kegiatan pendidik dapat dilakukan setiap hari bagian penting lainnya yang perlu diperhatikan bagi seorang pendidik adalah perlunya melibatkan siswa dalam evaluasi, sehingga pendidik secara baik dapat mengenali perkembangan pencapaian hasil pembelajaran pendidik.

Menurut Sukanti, Evaluasi proses pembelajaran bertujuan untuk memperbaiki dan mengoptimalkan kegiatan pembelajaran yang nantinya diharapkan dapat meningkatkan hasil belajar siswa. Untuk mengetahui seberapa jauh program pembelajaran dapat dilaksanakan, perlu membandingkan antara proses pembelajaran yang seharusnya dilaksanakan dengan proses pembelajaran yang senyatanya berlangsung. Keberhasilan proses pembelajaran dapat dilihat dari efisiensi, efektivitas, relevansi, dan produktivitasnya. ${ }^{1}$

Dalam kajian sebelumnya belum dibahas tentang evaluai secara detail, sehingga bagaimanakah cara mengetahui kemajuan kemajuan belajar peserta didik baik itu mengenai apa yang telah diperoleh ataupun yang telah diketahuinya dan juga mengevaluasi pendidikan terhadap siswa dan seberapa pentingkah evaluasi dalam pendidikan supaya dapat merencanakan apa yang seharusnya dilakukan selanjutnya akan diuraikan pada pembahasan berikut.

\section{B. PENGERTIAN EVALUASI}

Menurut pengertian istilah evaluasi merupakan kegiatan yang terencana untuk mengetahui keadaan suatu objek dengan menggunakan instrumen dan hasilnya dibandingkan dengan tolak ukur untuk memperoleh kesimpulan. Menurut Edwind wand dan Gerald w.brawn dalam bukunya Essentials of edu-

1 Sukanti, Evaluasi Proses Pembelajaran Sebagai Alternatif Meningkatkan Hasil Belajar, Jurnal Pendidikan Akuntansi Indonesia, Vol. 5 No. 2006 dalam https:// journal.uny.ac.id/index.php/jpakun/article/view/1781 
catiol dikatakan bahwa evaluation pefer to $\mathrm{tg} \backslash$ he act of proses to defermining the value of something (wang and brown 1957:1). Evaluasi adalah suatu tindakan atau suatu proses untuk menentukan nilai dari pada sesuatu. ${ }^{2}$

Penerapan evaluasi sangat penting bagi pendidik dengan adanya evaluasi pendidik dapat mengikuti kemajuan-kemajuan anak didiknya. Disamping itu pula evaluasi merupakan penilaian terhadap tingkat keberhasilan siswa untuk mencapai suatu tujuan yang telah ditetapkan dalam sebuah program dalam istilah lain evaluasi adalah assesssment yang berarti proses penilaian untuk menggambarkan prestasi yang dicapai seorang siswa sesuai dengan kriteria yang ditetapkan. Evaluasi juga dapat diartikan sebagai suatu kegiatan yang telah terencana untuk mengetahui tujuan-tujuan tertentu.

Dalam evaluasi membutuhakan suatu proses untuk mengumpulkan informasi yang baik untuk menetapkan sejauh mana ketercapain tujuan belajar. Untuk memperoleh informasi yang tepat dalam kegaitan evaluasi dilakukan melalui kegiatan pengukuran. Pengukuran merupakan suatu proses pemberian skor atau angka-angka terhadap suatu keadaan atau gejala, berdasarkan aturanaturan tertentu dengan demikian terdapat kaitan yang erat antara pengukuran dan evaluasi kegiatan pengukuran merupakan dasar dalam kegiatan evaluasi. Evaluasi merupakan suatu tindakan atau proses untuk mengumpulkan suatu informasi yang bermanfaat untuk pertimbangan dalam mengambil keputusan. Evaluasi merupakan alat, bukan tujuan yang digunakan untuk menilai sesuatu yang bermanfaat.

Assessment adalah serangkaian kegiatan yang dirancang untuk mengukur prestasi belajar (achievement) siswa sebagai hasil dari suatu program instruksional. Rumusan ini menunjukkan, bahwa hasil assessment terhadap siswa dapat digunakan sebagai bukti yang layak untuk dipertimbangkan dalam rangka evaluasi pengajaran. Jadi assessment bukan hanya menilai siswa melainkan sangat fungsional untuk menilai sistem pengajaran itu sendiri. ${ }^{3}$

Oleh karena itu peserta didik benar-benar membutuhkan assessment karena dengan adanya assessment peserta didik dapat mengukur hasil belajar dan mengukur tingkah laku agar bisa mencapai tujuan. Jika peserta didik tidak mengukur hasil belajar maka tidak akan bisa mencapai tujuan.

\footnotetext{
2 Sulistyorini, Evaluasi Pendidikan Dalam Meningkatkan Mutu Pendidikan, (Yogyakarta: Teras, 2009), 49.

3 Oemar Hamalik, Porses Belajar Mengajar, (Jakarta: Sinar Grafika, 2008), 146.
} 


\section{JENIS-JENIS EVALUASI}

Biasanya evaluasi dapat dibagi menjadi empat jenis, yaitu evaluasi formatif, sumatif, pelacement, dan diagnostic, keempat jenis evaluasi tersebut, secara singkat dan dibahas dari segi fungsi, tujuan aspek yang dinilai dan waktu pelaksanaannya.

\section{Evaluasi Formatif}

Evaluasi Formatif berfungsi untuk memperbaiki proses belajar mengajar kearah yang lebih baik, atau memperbaiki program satuan pelajaran yang telah digunakan. Dengan tujuan untuk mengetahui hingga dimana penguasaan murid tentang bahan yang telah diajarkan dalam suatu program satuan pelajaran.

Aspek-aspek yang dinilai dalam evaluasi formatif yaitu yang bekenaan dengan hasil kemajuan pelajar atau murid yang meliputi: pengetahuan, keterampilan, sikap dan penguasaan terhadap bahan pelajaran yang telah disajikan. waktunya yaitu setiap akhir pelaksanaan satuan program belajar-mengajar. ${ }^{4}$

Oleh karena itu evaluasi formatif penilaian yang dilakukan pada akhir atau ketika pelaksanaan program belajar untuk melihat tingkat keberhasilan atau sejauh mana tujuan yang telah dicapainya. Maka penilaian formatif dapat dilakukan setiap akhir pelaksanaan satuan program belajar-mengajar karena untuk memperbaiki proses belajar dan dapat memperbaiki program pengajaran yang telah terlaksana dilaksanakan. Dengan demikian guru dapat menilai muridnya dengan lebih baik dan teliti.

\section{Evaluasi Sumatif}

Evaluasi Sumatif berfungsi untuk menentukan angka atau nilai murid setelah mengikuti program pengajaran dalam satu catur wulan, semester, akhir tahun atau akhir dari suatu program bahan pelajaran dari suatu unit pendidikan. Di samping itu, untuk memperbaiki situasi proses belajar-mengajar kearah yang lebih baik serta untuk kepentingan penilaian selanjutnya. Hasil belajar yang dicapai oleh murid setelah menyelesaikan bahan pengajaran dalam satu catur wulan, semester, akhir tahun atau akhir suatu program bahan pengajaran pada suatu nilai unit pendidikan tertentu.

Evaluasi tersebut bertujuan untuk mengetahui taraf hasil belajar yang dicapai oleh murid setelah menyelesaikan program hasil pengajaran dalam satu catur wulan, semester, akhir tahun atau akhir suatu program bahan pengajaran

4 Mawardi Lugis, Evaluasi Pendidikan Nilai, 121. 
pada suatu nilai unit pendidikan tertentu. Sedangkan aspek-aspek yang dinilai ialah kemajuan belajar, meliputi: pengetahuan, keterampilan, sikap dan penguasaan murid tentang materi pelajaran yang sudah diberikan.Waktu pelaksanaannya akhir catur wulan, semester, atau akhir tahun. ${ }^{5}$

Dalam evaluasi sumatif merupakan hal yang dibutuhkan oleh pendidik karena bertujuan untuk mengetahui taraf-taraf hasil belajar yang telah dicapai dan bisa mengetahui seberapa jauh tujuan-tujuan belajar yang telah dikuasai oleh para siswa. Penilaian dilaksanakan oleh guru yang harus dilaksanakan pada akhir catur wulan, semester dan akhir tahun.

\section{Evaluasi Placement (penempatan)}

Evaluasi placement berfungsi untuk mengetahui keadaan anak termasuk keadaan seluruh pribadinya, agar anak tersebut dapat ditempatkan pada posisinya yang tepat. Dan bertujuan untuk menempatkan anak didik pada kedudukan yang sebenarnya, berdasarkan, minat, kemampuan, kesanggupan serta keadaan-keadaan lainnya, sehingga anak tidak mengalami hambatan dalam mengikuti setiap program atau bahan yang disajikan guru.

Aspek-aspek yang dinilai meliputi: keadaan fisik, psikis, bakat, kemampuan atau pengetahuan, keterampilan, sikap dan lain-lain. Aspek yang dianggap perlu bagi kepentingan pendidikan anak selanjutnya. Waktu penilaiannya sebaiknya dilaksanakan sebelum anak mengikuti proses belajar mengajar yang permulaaan atau anak tersebut baru akan mengikuti pendidikan disuatu tingkatan tertentu. ${ }^{6}$

Dalam suatu evaluasi penempatan peserta didik dapat mengetahui suatu keterampilan yang diperlukan dalam suatu program belajar dan penguasaan belajar seperti yang telah diprogramkan sebelum memulai kegiatan belajar untuk program itu. Dengan kesiapan siswa dapat menghadapi program baru dan kecocokan program belajar dengan kemampuan siswa. Dengan demikian pelaksanaannya harus sesuai apa yang akan dinilai sebelum proses belajar dimulai.

\section{Evaluasi Diagnostik}

Evaluasi diagnostik berfungsi untuk mengetahui masalah-masalah apa yang diderita atau yang menggangu anak didik, sehingga ia mengalami kesulitan, hambatan atau gangguan ketika mengikuti program tertentu. Dan bagai-

\footnotetext{
5 Abu Ahmadi Didudo Supriono, Psikologi Belajar, (Jakarta: PT.Rineka Cipta, 2004), 20.

6 Abu Ahmadi Didudo Supriono, Psikologi Belajar, 202.
} 
mana usaha untuk memecahkannya. Dan bertujuan untuk mengatasi / membantu pemecahan kesulitan atau hambatan yang dialami anak didik waktu mengikuti kegiatan belajar-mengajar pada suatu bidang studi atau keseluruhan program pengajaran. Aspek-aspek yang dinilai yaitu hasil belajar, latar belakang kehidupan anak, keadaan keluarga, lingkungan dan lain-lain. Evaluasi tersebut dapat dilaksanakan setiap saat sesuai dengan kebutuhan. ${ }^{7}$

Maka dari itu evaluasi diagnostic merupakan salah satu penilaian yang sangat penting bagi peserta didik karena bisa menjadi kelemahan-kelemahan yang dapat mengganggu prestasi siswa. Sehingga dapat mengatasi kesulitan atau hambatan untuk mencapai tujuan belajar. Dan bisa untuk mengatasi atau membantu nilai-nilai yang maksimal. Ketika peserta didik mengikuti program-program pendidikan, maka peserta didik harus benar-benar meneliti agar dapat menghasilkan nilai yang memuaskan. Tentunya soal-soal harus disusun agar dapat diketahui jenis kesulitan belajar yang di hadapi oleh para siswa. Penilaian ini dilaksanakan untuk keperluan bimbingan belajar, agar dapat terlaksana tujuan-tujuan pencapaian belajar.

\section{EVALUASI DALAM BELAJAR}

Evaluasi hasil belajar peserta didik di lakukan oleh pendidik untuk memantau proses, kemajuan dan perbaikan hasil belajar peserta didik secara berkenambungan, untuk mencapai tujuan tersebut uraian berikut mendiskusikan secara evaluasi yang di lakukan guru untuk menghasilkan kegiatan belajar yang lebih baik.

Evaluasi dalam belajar merupakan penilaian dalam melakukan kegiatan belajar, dalam peroses belajar terutama mengerjakan hal-hal yang sebenarnya, belajar apa yang diperbuat dan mengerjakan apa yang di pelajari kegiatan-kegiatan dan hasil-hasil belajar di persatukan dan di hubungkan dengan tujuan dalam pelajaran, evaluasi juga merupakan kegiatan yang di haruskan oleh guru karena tanpa penilaian guru tidak dapat mengetahui kemajuan belajar dan tujuan-tujuan yang di tempuh oleh pendidik,untuk mencapai tersebut. Untuk mencapai keberhasilan membutuhkan evaluasi, karena dengan evaluasi pendidik dapat mengukur tinggi dan rendahnya suatu pelajaran yang telah di kuasai oleh peserta didik.

Hasil evaluasi memberikan informasi tentang sejauh mana peserta didik telah menguasai bahan pelajaran yang disajikan.dengan informasi ini peserta

\footnotetext{
7 Ibid, 203.
} 
didik dapat mengambil langkah-langkah yang sesuai. Terdapat dua kemungkinan bagi peserta didik untuk mengambil sikap dan langkah yang sesuai tersebut. Apabila ternyata hasil evaluasi menunjukkan peserta didik itu belum mencapai tujuan instruksional yang di inginkan, peserta didik dapat di motivasi untuk belajar lebih giat lagi dan mencari upaya untuk menutup kekurangannya. Meskipun demikian, hasil serupa dapat mempunyai akibat negative bagi peserta didik, bahkan bisa peserta didik nantinya menjadi putus asa dan motivasi belajarnya menjadi menurun atau bahkan hilang sama sekali. Dan itu benar-benar hasil yang tidak memuaskan bagi peserta didik apabila hasil yang memuaskan peserta didik harus termotivasi terus, karena dengan motivasi peserta didik dapat belajar dengan giat lagi. Dan untuk mengulangi atau bahkan memperbaiki hasilnya supaya dapt memperoleh kepuasan yang serupa di waktu yang akan datang peserta didik merasa ada motivasi sekurang kurangnya mempertahankan tingkat kegiatan belajarnya atau malah lebih giat lagi belajar di waktu yang akan datang. Oleh karena itu dengan mempertahankan hasil belajar, peserta didik dapat termotivasi untuk belajar yang lebih giat lagi.

\section{E. EVALUASI DALAM PENDIDIKAN}

\section{Evaluasi Pendidikan}

Sesuai dengan pendapat tersebut maka evaluasi pendidikan dapat di artikan sebagai suatu tindakan atau suatu proses untuk menentukan nilai segala sesuatu dalam dunia pendidikan atau segala sesuatu yang ada hubungannya dengan dunia pendidikan. ${ }^{8}$

dalam evaluasi pendidikan selalu mengandung proses.proses evaluasi pendidikan harus tepat terhadap tipe tujuan yang biasa dinyatakan dalam bahasa perilaku. Dikarenakan tidak semua perilaku dapat dinyatakan dengan alat evaluasi yang sama, maka dari itu evaluasi menjadi salah satu hal yang sulit dan menentang,yang harus disadari oleh seorang guru evaluasi pendidikan dilakukan dalam rangka pengendalian mutu pendidikan secara nasional sebagai bentuk akuntalibitas penyelenggara pendidikan kepada pihak-pihak yang berkepentingan, diantaranya terhadap peserta didik, lembaga dan program pendidikan, sedangkan seorang guru perlu memahami metode evaluasi, yaitu cara-cara evaluasi yang digunakan oleh seseorang guru agar memperoleh informasi yang diperlukan.dari pemahaman bermacam-macam metode evaluasi tersebut. Kemudian dipilih yang paling tepat untuk dapat diterapkan kepada

\footnotetext{
${ }^{8}$ Sulistyorini, Evaluasi Pendidikan, (Yogyakarta: Teras, 2009), 102.
} 
peserta didik.

Dilihat dari aspek fungsi evaluasi pedidikan yang dilakukan dalam peroses belajar mengajar, pada perinsipnya dapat dibagi dua, membantu guru dalam menentukan derajat tujuan pengajaran agar dapat dicapai, membantu guru mengetahui keadaan yang benar dan pada siswanya. Fungsi kedua merupakan tujuan tambahan sebagai implikasi dan evaluasi dalam peroses pembelajaran.

Tugas guru dalam melakukan evaluasi pendidikan untuk membantu siswa dalam mencapai ilmu dan pendidikan yang telah ditetapkan agar tercapai tujuan pendidikan yang dimaksut, seorang guru lalu bertindak secara aktif dalam membantu setiap langkah dalam peroses pembelajaran. Tindakan aktif tersebut sebaiknya merupakan tindakan profesional yang dilakukan oleh seorang guru agar dikatakan bermakna apabila hasil akhirnya berorientasi pada tujuan pembelajaran dan diterapkan didalam kelas.

Tujuan pendidikan yang telah ditetapkan untuk dicapai sebaiknya ditunjukkan sejak dalam perencanaan, dan evaluasi pengajaran. Disamping itu, tujuan pendidikan pun dapat dilihat implikasinya dalam perilaku siswa. Siswa yang telah memahami dan menguasai materi yang diajarkan oleh seorang guru yang belum, hendaknya dapat dibedakan dalam kaitannya dengan adanya penunjukan dan adanya perubahan perilaku. Bentuk perilaku siswa itu biasanya dapat diidentifikasi dalam suatu fenomena atau indikator, misalnya pengetahuan, pemahaman, sikap, penghargaan atau apresiasi, keterampilan dan kemampuan siswa yang telah dispesifikasi dalam mata pelajaran. Dalam pendidikan pengertian tujuan dapat bervariasi maknanya tergantung dari aspek keluasan atau cakupan yang hendak dicapai. Dari aspek cakupan tersebut tujuan dapat dibedakan menjadi beberapa macam, misalnya tujuan nasional atau tujuan institusional atau tujuan umum, atau tujuan khusus. Dalam proses pembelajaran dikelas, tujuan yang perlu diperhatikan guru antara lain tujuan instruksional umum dan tujuan instruksional khusus. Perubahan perilaku yang telah direncanakan secara sistematik oleh seorang guru sebagai akibat pengalaman pendidikan dapat diungkapkan melalui proses evaluasi. Adapun metode yang digunakan untuk mengungkapkan informasi siswa, seorang guru sebaiknya selalu berusaha mencapai pada bentuk perilaku siswa dalam kaitannya dengan pengetahuan yang relevan. Semakin lengkap pengetahuan terhadap materi maupun fenomena tentang siswa yang diajari semakin baik dalam mempresentasikan evaluasi keadaan yang sebenarnya pada perilaku siswa.

Ada dua hambatan yang apabila tidak diperhatikan akan mencegah terjadinya evaluasi yang komprehensif terhadap tujuan pendidikan yang telah dite- 
tapkan. Pertama, kesulitan menerjemahkan tujuan pendidikan kedalam sikap, minat dan perilaku siswa. Seringkali terjadi perubahan yang terindentifikasi tidak mendalam dan cenderung hanya secara kasar saja. Kedua, dalam beberapa hal, perubahan total yang diinginkan siswa mungkin tidak terobservasi sampai jangka waktu yang lama termasuk berbulan-bulan, bahkan bertahun-tahun selama mengikuti proses pendidikan. Pendidik seharusnya dapat melihat perubahan pada peserta didik melalui beberapa aspek, diantaranya penguasaan ilmu pengetahuan, keterampilan, dan terpupuk rasa saling menghargai dengan sesama peserta didik.

Evaluasi pendidikan merupakan proses dimana seorang pendidik menggunakan informasi yang diturunkan beberapa sumber informasi agar dapat mencapai tingkat pengambilan keputusan. Informasi diperoleh dari hasil pengukuran menggunakan instrumen untuk menghasilkan data kuantitas tertentu, selain menghasilkan data juga mampu memberi informasi penting sebagai materi yang hendak dijadikan landasan terpercaya dalam pengambilan keputusan tentang peserta didik.

Dalam evaluasi pendidikan merupakan bagian terpenting yang harus dilakukan dalam dunia pendidikan. Tanpa adanya evaluasi maka jalan proses tidak akan pernah bisa diketahui seberapa besar hasil yang sudah dicapai.

Proses pendidikan tanpa adanya evaluasi akan mengakibatkan tujuan pendidikan tidak teratur secara nasional sehingga tingkat keberhasilan dari tingkat keberhasilan dan sebuah proses pendidikan tidak diketahui dan pendidikan akan berjalan tanpa tujuan yang jelas.

\section{Ciri-Ciri Evaluasi Pendidikan}

Ciri-ciri penilaian atau evaluasi dalam pendidikan, antara lain adalah sebagai berikut: penilaian dilakukan secara tidak langsung. Untuk dapat menentukan siswa mana yang lebih pandai dari yang lain. Maka bukan kepandaiannya yang diukur namun kita dapat mengukur kepandaian melalui kepandaiannya, salah satu contoh yaitu bahwa anak yang pandai biasanya dapat menyelesaikan soal-soal yang diberikan oleh guru.

Dalam penilaian membutuhkan kepandaian karena dengan kepandaian peserta didik bisa menjawab soal-soal yang diberikan oleh pendidik maka dari itu dengan kepandaianlah peserta didik bisa mencapai tujuan-tujuan tertentu, melalui kepandaian peserta didik bisa menampakkan gejala-gejala yang lebih baik dan dapat mengukur secara baik. 


\section{a. Reliabilitas}

Reliabilitas berarti dapat dipercaya, reliabilitas berarti dapat dipercayainya sesuatu. Tes yang reliable berarti tes itu dapat dipercaya. Suatu tes dapat dikatakan dapat dipercaya apabila hasil yang dicapai oleh tes itu konstan atau tetap dan tidak menunjukkan perubahan-perubahan. Unreliability suatu tes ini dapat disebabkan oleh dua faktor yaitu:

1. situasi pada waktu testing berlangsung

2. keadaan tes itu sendiri

Maka dari itu supaya dapat mengukur suatu tes peserta didik jika mendapatkan hasil yang memuaskan atau hasil yang sangat tinggi maka pendidik akan mudah dipercaya karena suatu tes dikatakan percaya. Dalam tes merupakan pertanyaan-pertanyaan yang mungkin tidak dapat dijawab, sebab kurang memberikan keterangan-keterangan yang lengkap, untuk mengatasi hal ini peserta didik harus benar-benar menyusun tes dan menguasi bahan yang akan diteskan dengan mendalam, dengan sesempurna mungkin.

\section{b. Validitas}

Valid berarti cocok atau sesuai, suatu tes dikatakan valid, apabila tes tersebut benar-benar menyasar kepada apa yang dituju, tes tersebut benar-benar dapat memberikan keterangan atau gambaran tentang apa yang diinginkan.

Dalam validitas merupakan tes yang memberikan gambaran tentang kemampuan dan kecakapan peserta didik, jika pendidik ingin mengetahui tentang kemampuan peserta didik, maka pendidik harus benar-benar mengetahui keterangan atau gambaran yang jelas.

\section{c. Obyektivitas}

Suatu tes dikatakan obyektif, apabila pendapat atau pertimbangan-pertimbangan dari pemeriksa tidak turut berpengaruh dalam proses penentuan angka atau proses scoring.

Maka dari itu didalam penentuan score dari jawaban-jawaban tes itu, maka hasilnya akan sama saja. Dengan demikian soal obyektivitas ini dilihat dari segi scoring. Peraktek yang ada dalam kehidupan sekolah, disamping testes obyektif terdapat pula tes-tes menurut pandangan sendiri ini peranan dari pihak pemeriksa adalah besar sekali. Sehingga dapat terjadi kemungkinan, dan bahkan sering terjadi kemungkinan, dan bahkan sering terjadi adanya perbedaan score dari dua orang pemeriksa terhadap suatu jawaban tes.

Meskipun demikian, didalam menyusun soal-soal tes, pendidik harus ber- 
usaha seobyektif mungkin. Pendidik harus mengusahakan agar unsur-unsur pandangan sendiri dan pada pemeriksa itu sejauh mungkin dihindarkan. Biarpun tidak dapat sama sekali dihilangkan, membuat tes yang hanya memerlukan jawaban-jawaban yang pendidik dan tepat didalam memeriksa, menggunakan kunci-kunci jawaban

\section{d. Praktikalibitas \{practicability\} yang telah disediakan sebelumnya.}

Sebuah tes dikatakan memiliki praktikalibitas yang tinggi, apabila tes tersebut bersifat praktis, mudah pengadministrasinya tes yang praktis adalah tes yang:

1. mudah dilaksanakan

2. mudah pemeriksaannya

3. dilengkapi dengan petunjuk-petunjuk yang jelas hingga dapat diberikan atau diawali oleh orang lain.?

\section{e. Ekonomis}

Yang dimaksud ekonomis disini ialah bahwa pelaksanaan tes tersebut tidak membutuhkan ongkos atau biaya yang mahal. Tenaga yang banyak, dan waktu yang lama. Ekonomis tidak harus buang-buang waktu dan tenaga karena ekonomis termasuk pengiritan agar tidak banyak membuang biaya.

\section{Fungsi Evaluasi Dalam Pendidikan}

Di samping karakteristik, evaluasi juga mempunyai fungsi yang bervariasi didalam proses belajar mengajar, yaitu sebagai berikut:

1. Sebagai alat untuk mengetahui pengetahuan, nilai-nilai, dan keterampilan yang telah diberikan oleh seorang guru.

2. Untuk mengetahui aspek-aspek kelemahan peserta didik dalam melakukan kegiatan belajar

3. Mengetahui tingkat ketercapaian siswa dalam kegiatan belajar.

4. Sebagai sarana umpan balik bagi seorang guru, yang bersumber dari siswa.

5. Sebagai alat untuk mengetahui perkembangan belajar siswa.

6. Sebagai materi utama laporan hasil belajar kepada pada orang tua siswa. ${ }^{10}$

\footnotetext{
9 Sulistyorini, Evaluasi Pendidikan, 163.

${ }^{10}$ Ibid, 165.
} 
Maka dari itu fungsi evaluasi sangatlah penting bagi para pendidik karena adanya fungsi evaluasi pendidik dapat merencanakan kegiatan evaluasi, dan sebaiknya perlu pertimbangan terlebih dahulu agar dapat mengetahui hasil-hasil yang dipeoleh oleh peserta didik.untuk mengetahui ketercapaian siswa dalam belajar kegiatan belajar membutuhkan pengukuran yang akan mengukur hasil-hasil belajar agar cepat tercapai tujuan-tujuan yang diinginkan oleh peserta didik.

Dalam kemajuan dan pertimbangan peserta didik harus melakukan kegiatan belajar selama beberapa hari atau waktu yang dibutuhkan. Maka dari itu pula pendidik dapat mengetahui sejauh mana peserta didik sudah mencapai tingkat keberhasilan.

Dalam penentuan kenaikan kelas prestasi yang diperoleh harus benarbenar baik dan hasil-hasil yang diperoleh harus tinggi dan baik agar sesuai dengan kelas yang akan ditempatinya.

Fungsi utama evaluasi adalah menelaah suatu objek atau keadaan untuk mendapatkan informasi yang tepat sebagai dasar untuk pengambilan keputusan. Maka dari itu fungsi evaluasi sangatlah penting bagi peserta didik karena dengan fungsi evaluasi peserta didik sangat mudah untuk mendapatkan informasi-informasi yang baik.

Dilihat dari aspek fungsi evaluasi pendidikan yang dilaksanakan dalam proses belajar-mengajar pada prinsipnya dapat dibagi dua, yaitu: membantu guru dalam menentukan derajat tujuan pengajaran agar dapat dicapai dan membantu guru mengetahui keadaan yang benar dari para siswanya. Fungsi utama merupakan tujuan mendasar dari evaluasi sedangkan fungsi kedua merupakan tujuan tambahan sebagai implikasi adanya evaluasi proses pembelajaran.

Tugas guru melakukan evaluasi pendidikan untuk membantu siswa dalam mencapai tujuan umum dari pendidikan yang telah ditetapkan, agar tercapai tujuan pendidikan yang dimaksud. Seorang guru perlu bertindak secara aktif dalam membantu setiap langkah dalam proses pembelajaaran. Tindakan aktif tersebut sebaiknya merupakan tindakan profesional yang dilakukan oleh seorang guru agar dikatakan bermakna apabila hasil akhirnya berorientasi pada tujuan pembelajaran yang ditetapkan didalam kelas.

\section{Tujuan Evaluasi Pendidikan}

Tujuan pendidikan merupakan tujuan yang bersifat luas untuk jangka panjang, maka dari itu tujuan makro ini merupakan tujuan khusus yang 
memiliki tujuan tertentu, tujuan pengajaran yang hendak dicapai disekolah mempunyai kaitan dengan materi yang hendak diberikan dan dengan metode belajar mengajar yang dipakai guru dan siswa dalam membedakan atau menerima materi tersebut. Sejauh mana keberhasilan guru memberikan materi, dan sejauh mana siswa menyerap materi yang disajikan itu dapat diperoleh informasinya melalui evaluasi. Evaluasi yang baik haruslah didasarkan atas tujuan pengajaran yang ditetapkan oleh guru dan kemudian benar-benar diusahakan pencapaiannya oleh guru dan siswa. Dengan demikian apabila ternyata hasil evaluasi peserta didik menunjukkan bahwa peserta didik belum mencapai tujuan instruksional yang diinginkan, ia dapat dimotivasi untuk belajar lebih giat lagi dan menerima upaya untuk menutupi kekurangannya.

Maka dari itu tujuan evaluasi pendidikan harus mengetahui manfaat evaluasi karena dengan mengetahui manfaat evaluasi peserta didik dapat mengetahui hasil pelajaran yang diberikan oleh pendidik. Dengan demikian keberhasilan kegiatan belajar dapat juga ditentukan pula oleh sekolah, hasil evaluasi yang diperoleh itu dapat dipakai sekolah untuk mrngontrol diri untuk melihat sejauh mana kondisi belajar berlangsung tetapi juga kondisi belajar tidak saja dimaksudkan situasi yang ada selama proses belajar berlangsung tetapi juga kondisi yang berhubungan dengan siswa, guru, orang tua siswa, dan sebagainnya. Siswa yang senang berkelahi, guru yang tingkat pendidikannya rendah, orang tua siswa yang yang acuh tak acuh terhadap perkembangan belajar anaknya semua itu merupakan kondisi yang mempersyaratkan kurangnya keberhasilan kegiatan belajar. Akan tetapi, apabila keadaannya justru sebaliknya, dapat diharapkan bahwa aktifitas belajarpun meningkat tinggi. Dan semua orang tua ingin melihat sejauh mana tingkat kemajuan yang dicapai anaknya disekolah, meskipun pengetahuan itu tidak menjamin adanya upaya dari orang tua untuk meningkatkan kemajuan anaknya. Oleh karena itu setiap semester, sekolah memberikan laporan kemajuan siswa kepada orang tuanya dalam bentuk buku rapor. Yang ada dalam buku rapor itu tidak lain hasil evaluasi yang dibuat oleh guru dan semua petugas sekolah terhadap siswa.

\section{F. PENTINGNYA EVALUASI DALAM PENDIDIKAN}

Evaluasi adalah suatu proses pengumpulan informasi secara sistematik untuk menetapkan sejauh mana ketercapaian tujuan belajar untuk memperoleh informasi yang tepat dalam kegiatan evaluasi dilakukan melalui pengukuran. Pengukuran merupakan suatu proses pemberian skor dari angka-angka terhadap suatu keadaan atau gejala, berdasarkan aturan-aturan tertentu. Dengan 
demikian terdapat kaitan yang erat antara pengukuran dan evaluasi kegiatan pengukuran merupakan dasar dalam kegiatan evaluasi. Evaluasi merupakan suatu tindakan atau proses untuk mengumpulkan suatu informasi yang bermanfaat untuk pertimbangan dalam mengambil keputusan. Evaluasi merupakan alat bukan tujuan yang digunakan untuk menilai segala sesuatu bermanfaat. Maka dari itu evaluasi merupakan bagian yang sangat penting dalam suatu sistem. Akan tetapi kesalahan utama yang sering terjadi diantara pendidik adalah bahwa evaluasi hanya dilakukan pada saat-saat tertentu. Akibat yang terjadi adalah minimnya informasi tentang para peserta didik sehingga menyebabkan banyaknya perlakuan prediksi pendidik menjadi bias dalam mentukan posisi peserta didik dalam kegiatan kelasnya. Dalam pengembangan instruksional, evaluasi hendaknya dilakukan semaksimal mungkin dalam suatu kegiatan. Ini dianjurkan karena untuk mendapatkan informasi yang banyak tentang kegiatan siswa dikelas dan kemudain digunakan untuk menilai tingkat keterlaksanaan program seperti yang telah direncanakan bagian penting lainnya yang perlu diperhatikan bagi seorang pendidik adalah perlunya melibatkan siswa dalam evaluasi sehingga pendidik dan peserta didik secara sadar dapat mengenali perkembangan hasil belajar peserta didik.

Dalam evaluasi pendidikan dapat mengukur pencapaian hasil belajar tapi perlu menggunakan ukuran secara kuantitatif yang menghasilkan kuantitatif baik dengan tes maupun dengan cara-cara lain. Maka dari itu evaluasi yang dilaksanakan sepanjang program pendidikan dan juga yang bernilai positif, yaitu yang mampu mendorong dengan mengembangkan kemampuan belajar siswa serta menyempurnakan program pelajaran, dan evaluasi juga dilakukan dengan cara membanding-bandingkan situasi sekarang dengan situasi lampau atau situasi yang sudah lewat, oleh karena itu dalam proses evaluasi bukan sekedar mengukur sejauh mana tujuan tercapaiannya prestasi pendidik akan tetapi juga digunakan untuk membuat keputusan. Evaluasi menekankan untuk menggunakan informasi yang diperoleh dengan pengukuran maupun dengan cara lain untuk menentukan pendapat dan membuat keputusan-keputusan pendidikan. Sebaliknya juga evaluasi tidak mungkin dilakukan tanpa pengukuran karena tanpa pengukuran pendidik tidak akan mengetahui kemajuankemajuan belajar yang dialami oleh peserta didik. Tetapi pendidik bukan hanya menilai melainkan mengetahui informasi-informasi yang diperoleh secara sistematik. Melalui evaluasi pendidik dapat mengetahui seluruh pengukuran, pengelolahan, penafsiran, dan pertimbangan untuk membuat keputusan tentang tingkat-tingkat keberhasilan belajar yang telah dicapai oleh peserta didik 
setelah melakukan kegiatan belajar dalam mencapaia tujuan pembelajaran yang telah ditetapkan. Maka dari itu hasil belajar menunjukkan pada prestasi belajar sedangkan prestasi belajar itu merupakan indikator adanya dan derajat perubahan tingkat laku siswa, hasil evaluasi mengambarkan kemajuan, kegagalan dan kesulitan masing-masing siswa. Maka dari itu evaluasi memiliki tujuan -tujuan tetentu: Memberikan informasi tentang kemajuan siswa dalam upaya pencapaian tujuan-tujuan belajar melalui berbagai kegiatan belajar, memberikan informasi yang dapat digunakan untuk mengetahui kemampuan siswa. Menetapkan kesulitan-kesulitannya dan menyarankan kegiatan-kegiatan perbaikan, memberikan informasi tentang semua aspek tingkah laku siswa sehingga guru dapat membantu perkembangannya menjadi warga masyarakat dan pribadi yang berkualitas.

Adapun aspek-aspek kepribadiannya yang ahrus diperhatikan dan merupakan objek didalam pelaksanaan evaluasi tersebut, menurut Nasrun Harahat, DKK, adalah berikut ini.

1. Aspek-aspek tentang berfikir, meliputi: intelegensi, ingatan, cara menginterpretasi dan, pokok- pokok pengerjaan, pemikiran yang logis, dan lain-lain.

2. Dari segi perasaan sosialnya meliputi: kerja sama dengan kawan sekelasnya, cara bergaul, cara pemecahan masalah serta nilai-nilai sosial, cara mengatasi dan menghadapi serta cara berpartisipasi dalam kehidupan sosial.

3. Dari kekayaan sosial dan kewarganegaraan meliputi: pandangan hidup atau pendapatnya terhadap masalah-masalah sosial, politik, dan ekonomi.

\section{G. PENUTUP}

Pengevaluasian guru terhadap siswa bisa membantu bagaimana siswa dapat mengetahui tujuan umum dari pendidikan yang telah ditetapkan dan untuk mengetahui seberapa jauh hasil yang telah dicapai siswa. Evaluasi pendidikan sangatlah penting dan sangat perlu karena dengan evaluasi pendidikan peserta didik dapat mengukur hasil belajarnya dan untuk menentukan sejauh mana tujuan pendidikan yang telah dicapainya. Melalui evaluasi pendidikan dapat diketahui kemajuan-kemajuan belajar yang terus dialami oleh peserta didik baik itu mengenai apa yang telah diperoleh ataupun yang telah diketahuinya dan juga dengan itu dapat merencanakan apa yang seharusnya dilakukan pada babak selanjutnya. 


\section{DAFTAR PUSTAKA}

Arifin, Zainal. Evaluasi Pembelajaran Prinsip, Teknik, Prosedur. Bandung: Remaja Rosda Karya, 2010.

Arikunto, Suharsimi. Dasar-Dasar Evaluasi Pendidikan. Edisi Revisi. Jakarta: Bumi Aksara, 2007.

B., Mahirah. "Evaluasi Belajar Peserta Didik (Siswa)." Jurnal IDAARAH 1, no. 2 (Desember 2017).

Hamalik, Oemar. Proses Belajar Mengajar. Jakarta: Bumi Aksara, 2007.

Kebudayaan, Kementerian Pendiidkan Dan. Kamus Besar Bahasa Indonesia. Edisi ke 5. Jakarta, 2016.

Lubis, Mawardi. Evaluasi Pendiidkan Nilai. Yogyakarta: Pustaka Pelajar, 2008. Mansyur. Asesmen Pembelajaran Di Sekolah. Cet. I. Yogyakarta: Multi Presindo, 2009.

Mulyasa, E. Menjadi Guru Profesional. Bandung: Rosda Karya, 2005.

Nasution. Teknologi Pembelajaran. Jakarta: Bumi Aksara, 2008.

Nurgiyantoro, Burhan. Penilaian Pembelajaran Berbasis Kompetensi. Yogyakarta: BPFE, 2010.

Purwanto, Ngalim. Prinsip-prinsip Evaluasi Pengajaran. Bandung: Rosda Karya, 2002.

Rukajat, Ajat. Teknik Evaluasi Pembelajaran. Yogyakarta: DEEPUBLISH, 2018.

Slameto. Belajar Dan Faktor-Faktor Yang Mempengarubinya. Cet. IV. Jakarta: Rineka Cipta, 2003.

Sudijono, Anas. Pengantar Evaluasi Pendidikan. Jakarta: PT. Grafindo Persada, 2005.

Sukanti. "Evaluasi Proses Pembelajaran Sebagai Alternatif Meningkatkan Hasil Belajar." Jurnal Pendidikan Akuntansi Indonesia 5, no. 2 (2006).

Sulistiyorini. Evaluasi Pendidikan Dalam Meningkatkan Mutu Pendidikan. Yogyakarta: Teras, 2009.

Supriyono, Abu Ahmadi \& Widodo. Psikologi Belajar. Jakarta: PT. Rineka Cipta, 2004.

Thoha, M. Chabib. Teknik Evaluasi Pendidikan. Jakarta: PT. Raja Grafindo, 
EVALUASI DALAM PENDIDIKAN SEBAGAI ALAT UKUR ...

2005.

Yusuf, A. Muri. Asesmen Dan Evaluasi Pendidikan. Jakarta: Kencana, 2017. 